Technological University Dublin ARROW@TU Dublin

\title{
Nanomole silver detection in chloride-free phosphate buffer using platinum and gold micro- And nanoelectrodes
}

\author{
Prabhakar Sidambaram \\ Technological University Dublin, prabhakar.sidambaram@tudublin.ie \\ John Colleran \\ Technological University Dublin, john.colleran@tudublin.ie
}

Follow this and additional works at: https://arrow.tudublin.ie/aegart

Part of the Chemistry Commons

\section{Recommended Citation \\ Sidambaram, Prabhakar \& Colleran, John. (2019). Nanomole Silver Detection in Chloride-Free Phosphate Buffer Using Platinum and Gold Micro- and Nanoelectrodes. Journal of The Electrochemical Society. 166. B532-B541. 10.1149/2.1371906jes.}

This Article is brought to you for free and open access by the Applied Electrochemistry Group at ARROW@TU Dublin. It has been accepted for inclusion in Articles by an authorized administrator of ARROW@TU Dublin. For more information, please contact arrow.admin@tudublin.ie, aisling.coyne@tudublin.ie, gerard.connolly@tudublin.ie.

Funder: Technological University Dublin

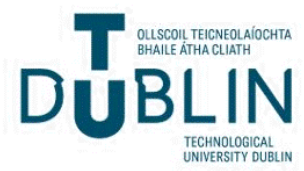


See discussions, stats, and author profiles for this publication at: https://www.researchgate.net/publication/332488065

\section{Nanomole Silver Detection in Chloride-Free Phosphate Buffer Using Platinum and Gold Micro- and Nanoelectrodes}

Article in Journal of The Electrochemical Society · January 2019

Dol: 10.1149/2.1371906jes

2 authors, including:

John J Colleran

Technological University Dublin - City Campus

19 PUBLICATIONS 329 CITATIONS

SEE PROFILE

Some of the authors of this publication are also working on these related projects:

FOCAS Research Institute View project 


\title{
Silver Detection in Chloride-Free Phosphate Buffer Using Platinum and Gold Micro and Nanoelectrodes
}

Prabhakar Sidambaram ${ }^{\mathrm{a}}$, John Colleran a,b

a Applied Electrochemistry Group, Dublin Institute of Technology, FOCAS Research Institute, Camden Row, Dublin 8, Ireland.

${ }^{b}$ School of Chemical and Pharmaceutical Sciences, Dublin institute of Technology, Kevin Street, Dublin 8, Ireland.

Email: john.colleran@dit.ie

\begin{abstract}
The electrochemical determination of ultra-low concentrations of silver requires reliable, reproducible measurements using sensitive analytical methods. To date, the electrochemical determination of silver in biological buffers and media has not been successful in terms of generating reproducible, reliable results. In this work, ultra-low concentrations of silver $(1 \mathrm{nM}-80 \mathrm{nM})$ were determined using micro and nanoelectrodes of platinum and gold in chloride-free phosphate buffer solution (PB) $\mathrm{pH} 7.4$, using anodic stripping voltammetry (ASV). The micro and nanoelectrodes were fabricated using a Sutter P-2000 laser puller, with physical and electrochemical characterisation revealing flat disk-shaped working areas of $10-15 \mu \mathrm{m}$ (microelectrode) and $10-100 \mathrm{~nm}$ (nanoelectrodes) in radius. These dimensions were calculated from steady-state limiting currents and confirmed using FE-SEM. The laser pulled electrodes exhibit excellent electrochemical activity when characterised using ferrocene, without the addition of supporting electrolyte, and reproducible stripping voltammetric profiles for the determination of silver were obtained. Determination of ultra-low concentrations of silver in chloridefree PB provides the scope to explore the mechanism of action of bioinorganic silver-based antibacterial, anti-fungal and anti-cancer drugs in cell media for in vitro and, potentially, in vivo analysis.
\end{abstract}




\section{TOC (Table of Graphic Content)}

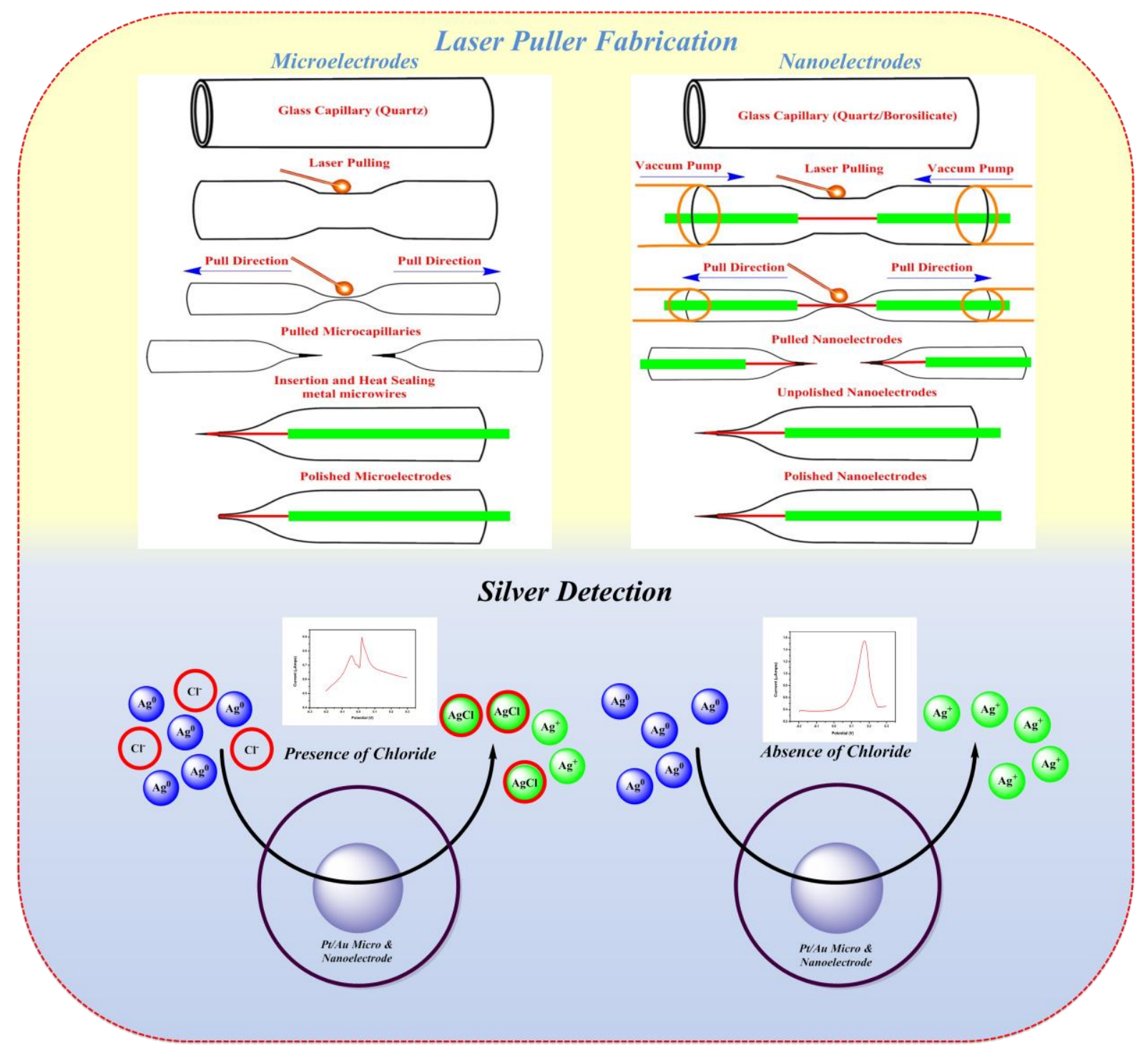

\section{Keywords}

Silver detection; $\mathrm{Ag} / \mathrm{AgBr}$ reference electrode; Chloride-free phosphate buffer (PB) solution; Anodic stripping voltammetry (ASV); Laser puller fabrication; Gold and platinum; Micro and nanoelectrodes 


\section{Introduction}

Throughout history, the use of metal-based compounds in therapeutics and for medicinal purposes has been practised. The discovery of the bioinorganic platinum-based drug, cisplatin, in the 1960's, shifted scientific interest towards metal-based compounds for medicinal applications, particularly in cancer treatment. ${ }^{1}$ A recent significant review, highlighting the challenges associated with current Ptbased drugs, explores the potential of other metal-based drugs, providing an insight into the future of drug development. ${ }^{2}$ There is a considerable range of bioinorganic compounds reported based on different chelating metals ( $\mathrm{Pt}, \mathrm{Ru}, \mathrm{Cu}, \mathrm{Ir}, \mathrm{Rh}, \mathrm{Sn}$, and $\mathrm{Ag}$ ) and ligands. ${ }^{3,4}$ Metallic silver has been widely used as an anti-microbial agent and in other medicinal applications, namely, as antiseptics, anti-microbial, and anti-inflammatory drugs. ${ }^{5}$ Bioinorganic silver compounds have also risen to prominence in recent years, due to their potential in cancer therapy. ${ }^{6,7}$ Some bioinorganic compounds are known to generate free radicals and can directly bind to DNA, inhibiting cell replication, and cell division and actively induce apoptosis. ${ }^{8,9}$ The release and dissolution of complexed silver (I) ions also plays a vital role in the anti-microbial and anti-cancer properties of silver. ${ }^{10}$ Free silver (I) ions can bind to the surface of the cell membrane and can inhibit cellular respiration or disorient the metabolic activities of the cell. Silver (I) ions are reported to have superior bioactivity when complexed with suitable ligands but, to date, the mechanism of action of silver complexed drugs is not clearly understood. ${ }^{6}$ Understanding the mode of action of the metal-ligand drugs can be achieved by monitoring the metal ions and organic complexes thereof, at the cellular level, and should help pave the way to create highly efficient, application-specific, silver-based bioinorganic drugs.

The detection and determination of silver has been studied extensively over the past few decades, employing several different analytical methods and materials. Among these methods, electrochemical detection of silver has several advantages, such as, low cost, experimental simplicity, equipment portability, low sample volume, and high sensitivity over other techniques. ${ }^{11-18}$ Electrochemistry facilitates the analysis, detection, and determination of trace metals by various techniques such as anodic stripping voltammetry (ASV), differential pulse voltammetry (DPV) and square wave anodic stripping voltammetry (SWASV). Anodic stripping voltammetry, with background subtraction (subtractive stripping), is a very effective analytical tool that involves the preconcentration, and deposition of the metal on the electrode surface, followed by selective oxidation of the deposited metal species during an anodic potential sweep. ASV is a very sensitive and reproducible method for the detection of trace metals at low concentrations. ${ }^{19}$ To date, the electrochemical detection and determination of ultra-low concentrations of silver in biological buffers has not been very successful. ${ }^{14,15,20}$ To this end, some key issues have to be addressed; the electrolyte composition, $\mathrm{pH}$, and detection technique all play important roles, ${ }^{21}$ and the presence of chloride ions in the electrolyte system greatly influences experimental reproducibility. ${ }^{15,22,23}$

Optimizing the electrochemical parameters can increase the sensitivity and selectivity of the chosen method towards the detection of ultra-low concentrations of silver in chloride-free biological buffer (PB, pH 7.4). Further enhancement arises from the performance of the electrode when scaled down to micro and nano dimensions. Nanoelectrodes have advantageous properties, such as, higher mass transfer efficiency, smaller RC cell time constants, a lower $i R$ drop, higher signal-noise ratios, and higher current densities, when compared to conventional electrodes. ${ }^{24}$ As the dimension of electrodes approaches the nanoscale, properties deviate from classical electrode chemistry. Nanoelectrodes have very high mass transfer efficiency when the diffusion layer thickness approaches the Debye length. The diffusion layer thickness varies and acts as a spherical electrode at the edge of the diffusion layer, depending on the experimental timescale. ${ }^{25,26}$ Micro and nanoelectrodes can be fabricated by various techniques such as electrochemical/chemical etching of fabricated electrodes followed by 
electrodeposition of the desired metal, ${ }^{27}$ Taylor's method, ${ }^{28}$ lithography for micro and nanoelectrode single/arrays ${ }^{29}$ and by the laser pulling method. The reported use of laser pulling to fabricate single micro and nanoelectrodes is summarised in Table 1. In cellular conditions, concentrations of the species of interest will be low and, thus, single micro and nanoelectrodes are ideal candidates for intercellular and extracellular electrochemical detection. ${ }^{30,31}$

\begin{tabular}{|c|c|c|c|c|}
\hline $\begin{array}{l}\text { Electrode } \\
\text { Material } \\
\end{array}$ & Technique & $\begin{array}{l}\text { Electrode } \\
\text { Dimension }\end{array}$ & Application & Reference \\
\hline Platinum & $\begin{array}{l}\text { Glass puller and } \\
\text { electrodeposition }\end{array}$ & $60 \mathrm{~nm}$ & $\begin{array}{l}\text { In vitro detection } \\
\text { of ROS and RNS } \\
\text { at the single-cell } \\
\text { level }\end{array}$ & $\begin{array}{l}\text { Christian } \\
\text { Amatore }^{27}\end{array}$ \\
\hline $\begin{array}{l}\text { Platinum and } \\
\text { Gold }\end{array}$ & $\begin{array}{l}\text { Laser puller and } \\
\text { electrodeposition* }\end{array}$ & $\begin{array}{l}1-3 \mathrm{~nm} \text { and } 4 \\
\mathrm{~nm}\end{array}$ & $\begin{array}{l}\text { Measure } \\
\text { heterogeneous ET } \\
\text { rates and } \\
\text { electrocatalysis }\end{array}$ & Bo Zhang ${ }^{32,33}$ \\
\hline $\begin{array}{l}\text { Platinum, carbon, } \\
\text { gold, silver, and } \\
\text { mercury }\end{array}$ & Laser puller & $\begin{array}{l}50 \mathrm{~nm}, 7 \mu \mathrm{m}, \\
10 \mu \mathrm{m}, 25 \mu \mathrm{m} \text { and } \\
25 \mu \mathrm{m}\end{array}$ & $\begin{array}{l}\text { SECM } \\
\text { measurements }\end{array}$ & $\begin{array}{l}\text { Janine } \\
\text { Mazeroll }^{34,35}\end{array}$ \\
\hline Platinum & Laser Puller & $2-500 \mathrm{~nm}$ & $\begin{array}{l}\text { Kinetics of ET } \\
\text { and SECM } \\
\text { imaging of living } \\
\text { cells }\end{array}$ & $\begin{array}{l}\text { Michael V. } \\
\text { Mirkin }^{36,37}\end{array}$ \\
\hline Platinum & Laser Puller & $50-300 \mathrm{~nm}$ & $\begin{array}{l}\text { Detect dilute } \\
\text { electroactive } \\
\text { species and dual } \\
\text { electrodes }\end{array}$ & Peng Sun ${ }^{38,39}$ \\
\hline Platinum & Laser Puller & $10 \mathrm{~nm}$ & $\begin{array}{l}\text { SECM } \\
\text { measurement }\end{array}$ & $\begin{array}{l}\text { Wolfgang } \\
\text { Schumann }^{40}\end{array}$ \\
\hline Gold & Laser Puller & $5 \mathrm{~nm}$ & $\begin{array}{l}\text { Electrochemistry } \\
\text { of ferritin and E- } \\
\text { DNA sensor }\end{array}$ & Yongxin $\mathrm{Li}^{41,42}$ \\
\hline $\begin{array}{l}\text { Carbon fiber } \\
\text { electrode }\end{array}$ & $\begin{array}{l}\text { Micropipette } \\
\text { puller }\end{array}$ & $100 \mu \mathrm{m}$ & Detection of $\mathrm{H}_{2} \mathrm{O}_{2}$ & $\begin{array}{l}\text { Leslie A. } \\
\text { Sombers }^{43}\end{array}$ \\
\hline Platinum & Laser Puller & $110 \mathrm{~nm}$ & $\begin{array}{l}\text { ESD damage to } \\
\text { nanoelectrodes }\end{array}$ & $\begin{array}{l}\text { Shigeru } \\
\text { Amemiya }^{44}\end{array}$ \\
\hline
\end{tabular}

Table 1: Literature summary of single micro and nanoelectrodes fabricated using the laser puller method (*nanopore formation and electrodeposition).

This body of work focusses on the fabrication, characterisation, and application of gold and platinum micro and nanoelectrodes. The micro and nanoelectrodes were characterised by FE-SEM imaging and electrochemically, using the redox probe ferrocene. The electrodes were then used to detect and determine silver at ultra-low concentrations $(1 \mathrm{nM}-80 \mathrm{nM})$ in biological buffer PB (chloride-free solution, $\mathrm{pH}$ 7.4). The electrochemical deposition and stripping analysis experiments were carried out in a three-electrode system using $\mathrm{Ag} / \mathrm{AgBr}$ as a quasi-reference electrode. In all the electrochemical analysis, chlorides were deliberately omitted, and meticulous electrode cleaning was implemented, 
resulting in the generation of reproducible calibration curves for silver detection at gold and platinum micro and nanoelectrodes.

\section{Materials, Chemicals, and Instrumentation}

All chemicals were used as received from suppliers without further purification; silver nitrate $\left(\mathrm{AgNO}_{3}\right)$, nitric acid $\left(\mathrm{HNO}_{3}\right)$, hydrobromic acid $(\mathrm{HBr})$, potassium bromide $(\mathrm{KBr})$, monopotassium phosphate $\left(\mathrm{KH}_{2} \mathrm{PO}_{4}\right)$, dipotassium phosphate $\left(\mathrm{K}_{2} \mathrm{HPO}_{4}\right)$, potassium nitrate $\left(\mathrm{KNO}_{3}\right)$, sodium nitrate $\left(\mathrm{NaNO}_{3}\right)$, sulphuric acid $\left(\mathrm{H}_{2} \mathrm{SO}_{4}\right)$, acetonitrile $(\mathrm{ACN})$ and ferrocene $\left(\mathrm{Fe}\left(\mathrm{C}_{5} \mathrm{H}_{5}\right)_{2}\right)$.

Quartz capillaries (O.D - $1.0 \mathrm{~mm}$; I.D - $0.3 \mathrm{~mm} \& 0.7 \mathrm{~mm}$ ), and borosilicate capillaries (O.D - $1.0 \mathrm{~mm}$; I.D - $0.3 \mathrm{~mm}$ ) were purchased from Sutter Instruments. $25 \mu \mathrm{m}$ diameter platinum wire (hard tempered) and gold wires (annealed) were purchased from Goodfellow and Alfa Aesar. Glass sealed gold microwires were generously donated by ELIRI, Moldova. ${ }^{45}$

A Solartron potentiostat, model 1285 , was used for experiments involving microelectrodes, while a $\mathrm{CH}$ Instruments potentiostat, model 620a, was used for nanoelectrode work. All electrochemical measurements were made using a three electrode system; gold and platinum micro, and nanoelectrodes were used as working electrodes, platinum wire as the counter electrode and $\mathrm{Ag} / \mathrm{AgBr}$ as a quasi-reference electrode (silver detection), a nonaqueous $\mathrm{Ag} / \mathrm{Ag}^{+}$reference electrode (for ferrocene in acetonitrile, cyclic voltammetry) and a saturated calomel reference electrode (for aqueous cleaning of the electrodes). All electrochemical experiments were conducted at room temperature, in a home-made Faraday cage.

Phosphate Buffer Solution 0.1 M and 0.01 M (chloride-free PB) - 0.1 M K $\mathrm{KH}_{2} \mathrm{PO}_{4}, 0.1 \mathrm{M} \mathrm{K}_{2} \mathrm{HPO}_{4}$, $0.0027 \mathrm{M} \mathrm{KNO}_{3}$ and $0.137 \mathrm{M} \mathrm{NaNO}_{3}$ (only phosphates and nitrates salts were used) were prepared using ultrapure water $\left(18 \mathrm{M} \Omega \mathrm{cm}^{-1}\right.$, Milli-Q) for $0.1 \mathrm{M} \mathrm{PB}(\mathrm{pH}-7.4)$ and $0.01 \mathrm{M} \mathrm{PB}$ was prepared by further diluting the $0.1 \mathrm{M} \mathrm{PB}(\mathrm{pH}-7.4)$.

Silver nitrate - A stock solution of $0.1 \mathrm{M}$ silver nitrate was prepared and kept in the dark to protect it from light exposure. The working solutions were prepared by dilution of the stock solution for the desired concentration $(1 \mathrm{nM}-1 \mu \mathrm{M})$.

\section{Preparation of Ag/AgBr Reference Electrode}

$1 \mathrm{M}$ hydrobromic acid and $0.05 \mathrm{M}$ potassium bromide were used for the bromination of silver wires when preparing $\mathrm{Ag} / \mathrm{AgBr}$ quasi-reference electrodes. Galvanostatic deposition of bromide on to a silver wire was performed by applying a current of $10.16 \mathrm{~mA}$ to the wire for 1 hour in a solution of $1 \mathrm{M} \mathrm{HBr}$. The bromidized silver wire was then soaked in $0.05 \mathrm{M}$ potassium bromide for 3 hours. ${ }^{46}$

Ferrocene $-1 \mathrm{mM}$ ferrocene solution was prepared by dissolving $0.0186 \mathrm{~g}$ of ferrocene in $100 \mathrm{ml}$ of acetonitrile solution without supporting electrolyte.

Sulphuric acid - Sulphuric acid solution of $0.1 \mathrm{M}$, was prepared using ultrapure water $\left(18 \mathrm{M} \Omega \mathrm{cm}^{-1}\right.$, Milli-Q), and used for electrode cleaning.

\section{Physical and Electrochemical Characterization}

A Hitachi SU-6600 FE-SEM and S5500 FE-SEM (Field Emission-Scanning Electron Microscopy) were used to acquire FE-SEM images in performing the physical and morphological characterisation 
of the micro and nanoelectrodes. The samples were imaged as fabricated and no additional coating or sputtering was required.

\section{Silver Detection}

Anodic stripping voltammetry was employed to determine and quantify silver solution concentrations using micro and nanoelectrodes in chloride-free $\mathrm{PB}$ at $\mathrm{pH}$ 7.4. The optimal deposition potential $-0.3 \mathrm{~V}$ was determined and applied to the electrodes for a duration of 1 minute, and for 30 seconds, for the micro, and nanoelectrodes, respectively. The stripping experiments were repeated a minimum four times, to obtain reproducible stripping charge (total charge transferred during the oxidation of silver at the electrode surface) values from the same electrode. The electrodes were cleaned rigorously between experiments, and background profiles were obtained prior to silver deposition. After each stripping analysis, the electrodes were cleaned by cycling in $0.1 \mathrm{M} \mathrm{H}_{2} \mathrm{SO}_{4}$ for 10 cycles. The silver stripping experiments were carried out at scan rates of $100 \mathrm{mV} / \mathrm{s}$ and $10 \mathrm{mV} / \mathrm{s}$ for the micro and nanoelectrodes, respectively.

\section{Fabrication of Microelectrodes}

Cleaning of the Capillaries - All the capillaries were soaked in $10 \%$ v/v nitric acid ( $1-2$ hours), rinsed in ultrapure water and dried in an oven at $100^{\circ} \mathrm{C}-120^{\circ} \mathrm{C}$ overnight. For successful fabrication of the microelectrodes, three steps have to be followed as shown in Figure $\mathbf{1 a}$.

1) Micropipette Fabrication - The quartz capillaries (O.D - $1.0 \mathrm{~mm} \& \mathrm{I} . \mathrm{D}-0.7 \mathrm{~mm}$ ) were mounted on the Sutter P-2000 laser puller, and the following program parameters were applied

$$
\text { Heat - 700; Filament - 4; Velocity - 60; Delay - 145; Pull - } 175
$$

2) Heat Sealing - Approximately, 2-3 cm lengths of Au and Pt wire of $25 \mu \mathrm{m}$ diameter were inserted into the pulled micropipette. Prior to heat sealing of the electrodes, the $\mathrm{Au}$ and $\mathrm{Pt}$ wires were glued to copper wires using conductive silver epoxy to make an electrical connection. The metal wires were positioned near the tip of the quartz micropipettes, and heat sealed using a glow torch. Care was taken while sealing the wire, as excessive heat applied to the tip and tapered region can melt the metal wire (gold wire has a lower melting point than platinum, so direct contact of the tip region with the flame was avoided). 

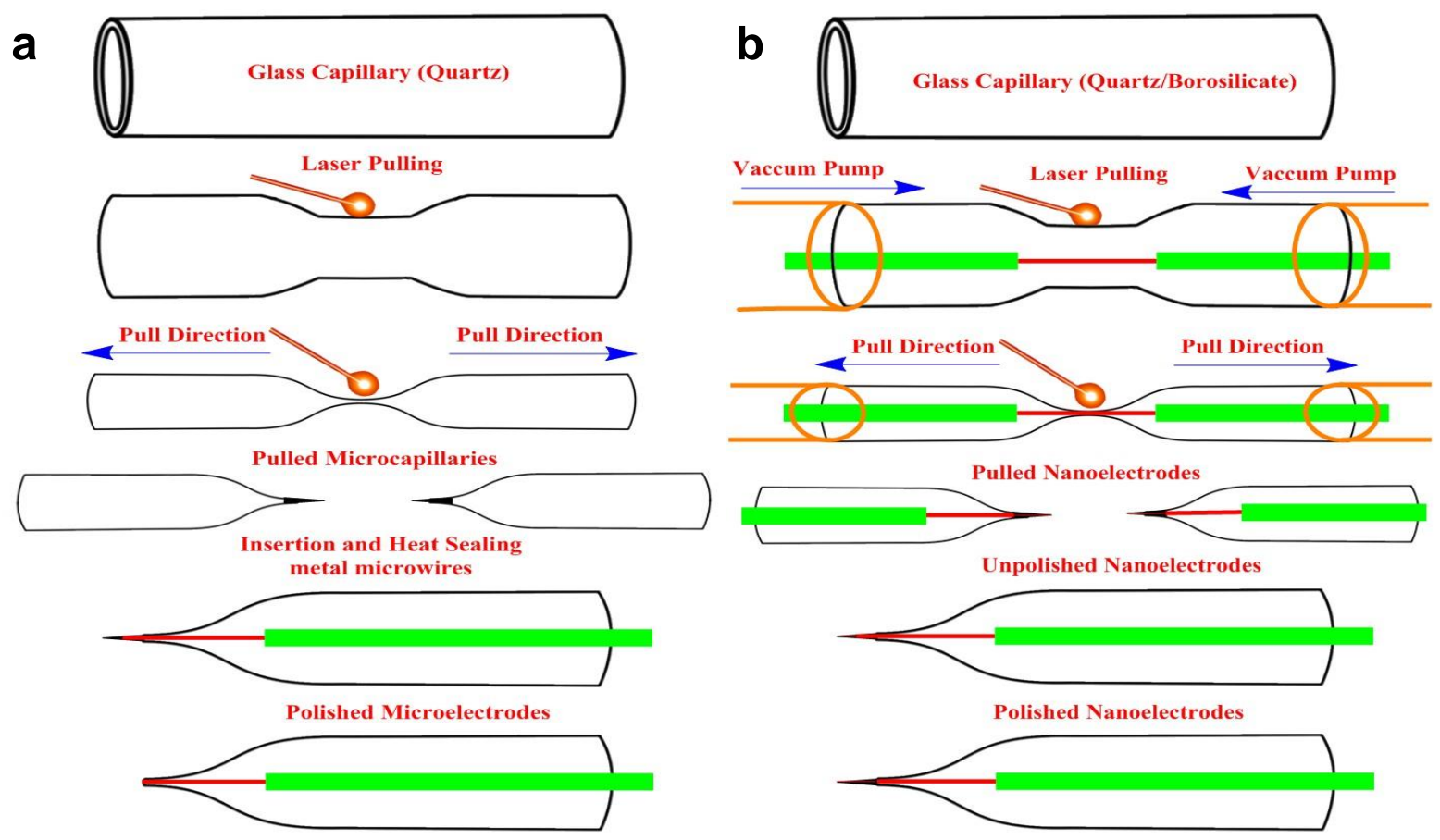

Figure 1: Graphical representation of the fabrication process for a) micro and b) nanoelectrodes. Capillaries loaded with gold and platinum microwires were laser pulled forming the microelectrodes. For nanoelectrode fabrication, laser pulled heat sealed capillaries were used.

3) Polishing - The heat-sealed microelectrodes were polished with the Sutter BV-10 beveler to expose the electroactive metal surface. Exposure of the metal tip was confirmed using an insitu impedance meter (BVM-CE).

\section{Fabrication of Platinum Nanoelectrodes}

1) Pre-thinning - After cleaning the quartz capillaries, a 2-3 cm length of Pt wire, $25 \mu \mathrm{m}$ diameter, was inserted into the $7.5 \mathrm{~cm}$ long quartz capillary with the help of a stereo microscope. The capillaries were mounted on the P-2000 laser puller, and the open ends were connected to a vacuum pump using Y-connector tubes, to remove any gas formed during heating as shown in Figure $\mathbf{1 b}$. The following program was carried out to pre-thin quartz capillary. Home-made stoppers were used to avoid the movement of the puller bars during pre-thinning.

\section{Heat - 650; Filament - 2; Velocity - 40; Delay - 140; Pull - 0}

2) Sealing - The metal wire was completely sealed inside the pre-thinned capillaries using the program parameters:

\section{Heat - 850; Filament - 5; Velocity - 100; Delay - 120; Pull - 0}

This program was cycled five times, to ensure proper sealing between the wire and the glass capillary. It was observed, that for proper sealing, the Heat and Filament parameters play significant roles. Before each cycling step, the capillaries were examined under the microscope to check the quality of the seal and to ensure the metal had not melted. The 
program was repeated for the desired cycle number, with each cycle consisting of 40 seconds of heating and a 20 second cooling period.

3) Hard Pulling - Once the sealing process was completed, hard pulling was initiated using the program parameters:

$$
\text { Heat - 810; Filament - 2; Velocity - 60; Delay - 100; Pull - } 200
$$

The vacuum was switched off and the stoppers were removed before the hard pulling. The hard pulling process has to be initiated within 20 seconds of completing the sealing process. Any delay in the time between the sealing and hard pulling processes allows the capillary to cool down, affecting the reproducibility of the process.

4) Polishing - The pulled electrodes were mounted on to the manipulator at an angle of $90^{\circ}$ to the top of the polishing plate. Polishing of the electrode was carried out on the diamond abrasive plate to remove the excess glass at the tip, exposing the active metal surface. This fabrication procedure results in flat electroactive disk-shaped nanoelectrodes. Conductive silver epoxy was used to make electrical contact between the copper and electrode metal wires.

\section{Fabrication of Gold Nanoelectrodes}

The fabrication of gold nanoelectrodes follows a slightly different procedure and program parameters from that of the platinum nanoelectrodes, due to the difference in the melting points of gold $\left(1064^{\circ} \mathrm{C}\right)$ and platinum $\left(1768^{\circ} \mathrm{C}\right)$. Initial attempts to fabricate gold nanoelectrodes resulted in discontinuous beading of the wire leading to failed nanoelectrodes. Glass sealed gold microwires, produced using Taylor's wire process, were used which prevents bead formation. ${ }^{47}$ The glass sealed gold microwires of different diameters were very generously donated by ELIRI, Moldova. ${ }^{45}$

In this work, glass sealed gold microwire of $24.1 \mu \mathrm{m}$ diameter of gold and $43 \mu \mathrm{m}$ glass outer diameters were used. The glass sealed gold microwire was inserted into borosilicate capillary $(\mathrm{O} . \mathrm{D}-1.0 \mathrm{~mm} \& \mathrm{I} . \mathrm{D}-0.3 \mathrm{~mm})$ and pulled using the laser puller. Gold nanoelectrodes were fabricated after the pre-thinning, sealing, and hard pulling steps. The laser pulled gold nanoelectrodes were polished and electrical connections made.

$$
\text { Heat - 310; Filament - 1; Velocity - 100; Delay - 120; Pull - } 180
$$

\section{Results and Discussion}

\section{Characterization of Micro and Nanoelectrodes}

The fabricated gold and platinum micro and nanoelectrodes were imaged using FE-SEM, which provides good evidence for the 2-D surface morphology. From Figure 2, a well-defined flat disk shape of the metal tip on the micro and nanoelectrode can be observed. The radii of the gold and platinum microelectrodes, imaged by FE-SEM, were 17 and $10 \mu \mathrm{m}$, respectively as shown in Figure $2 \boldsymbol{a}$ and $\boldsymbol{b}$. The gold and platinum nanoelectrodes were $300 \mathrm{~nm}$ (further polished to reduce charging effect during SEM imaging) and $100 \mathrm{~nm}$, respectively, as shown in Figure $2 \boldsymbol{c}$ and $\boldsymbol{d}$. The steady-state voltammograms of ferrocene, obtained at the electrodes utilised for FE-SEM images shows that the diffusion controlled steady-state currents are $75 \mathrm{pA}$ and $87 \mathrm{pA}$ for the gold and 
platinum nanoelectrodes. From these steady-state currents the effective radii were calculated as $90 \mathrm{~nm}$ for platinum and $73 \mathrm{~nm}$ for gold.

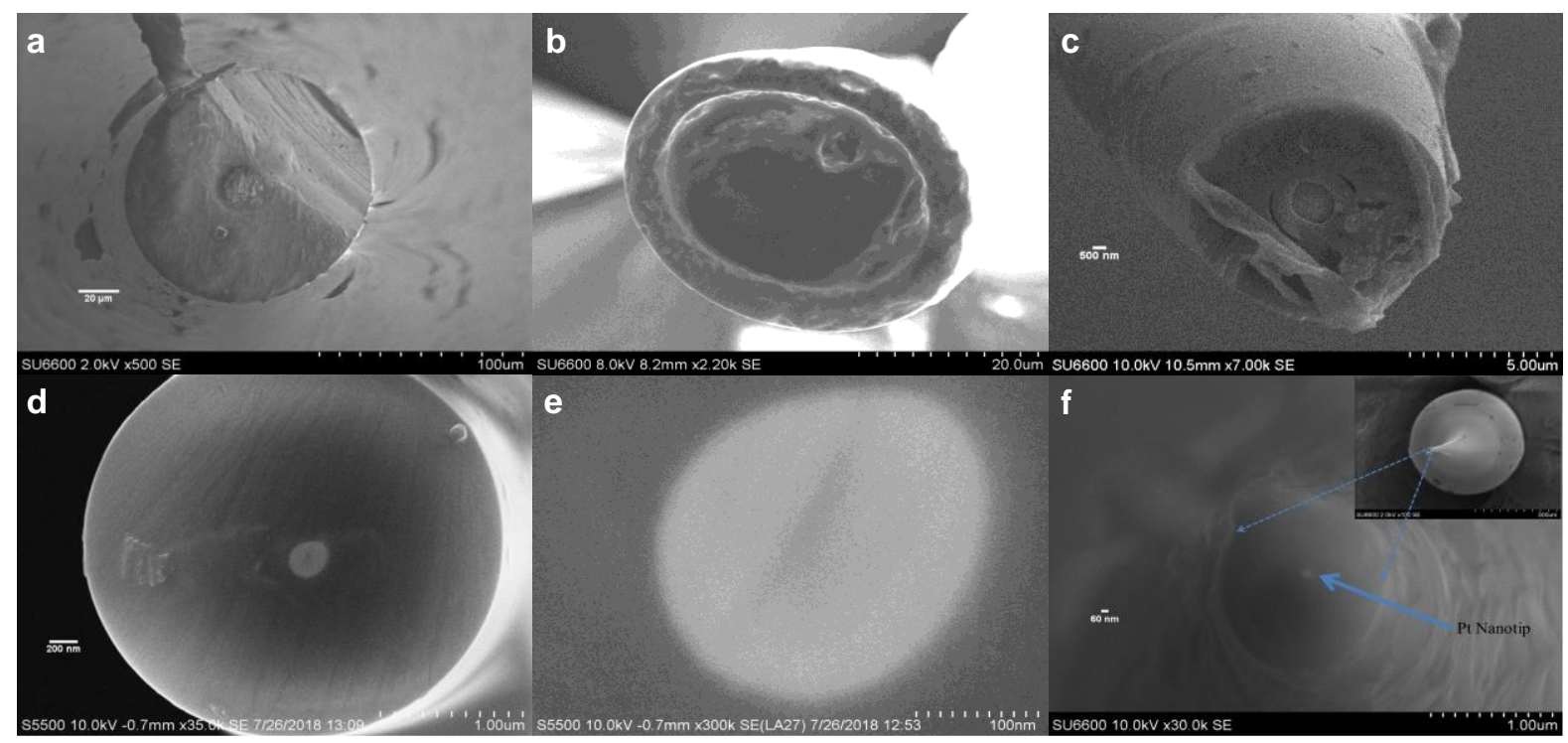

Figure 2: SEM images are showing the surface morphology of the electrode tips; a) platinum microelectrode $(10 \mu \mathrm{m})$ polished at an angle of $45^{\circ}$ and $90^{\circ}$, showcasing the smoothness of electrode polishing; b) gold microelectrode $(17 \mu \mathrm{m}) ; \mathrm{c})$ gold nanoelectrode (outer and inner glass capillary encasing the gold wire); d) platinum nanoelectrode of $200 \mathrm{~nm}$ diameter and e) imaged using lowangle backscattering; f) platinum nanoelectrode tip of $30 \mathrm{~nm}$ in radius (insert: nanoelectrode tip showing taper and untapered region).

The platinum microelectrode in Figure $2 \boldsymbol{a}$ was polished at an angle of $45^{\circ}$ and $90^{\circ}$ to evaluate the quality of polishing and to provide a smooth uniform flat circular electrodes surface. In Figure $\mathbf{2 b}$, the gold microelectrode of radius $17 \mu \mathrm{m}$ reveals a proper concentric sealing of the gold wire within the insulating glass capillary. The gold nanoelectrode, shown in Figure $2 \boldsymbol{c}$, presents outer and inner glass capillaries encasing the gold wire. A $100 \mathrm{~nm}$ radius platinum nanoelectrode is shown in Figure $2 \boldsymbol{d}$ and $\boldsymbol{e}$, (Figure $2 \boldsymbol{e}$ was imaged using low-angle backscattering). Figure $2 \boldsymbol{f}$ (insert: nanoelectrode tip with taper and untapered region) shows a platinum nanoelectrode tip radius of $30 \mathrm{~nm}$.

\section{Voltammetric Response of Micro and Nanoelectrodes}

The ferrocene/ferrocenium $\left(\mathrm{Fc} / \mathrm{Fc}^{+}\right)$couple is an excellent redox probe to investigate the properties of the fabricated electrodes. Steady-state voltammetry performed in $1 \mathrm{mM}$ ferrocene solutions was used to characterise the Au, Pt micro and nanoelectrode surfaces. The FE-SEM images confirm the integrity of the electrodes and that the geometry of each micro and nanoelectrode active surface is flat and disk-shaped. 
a

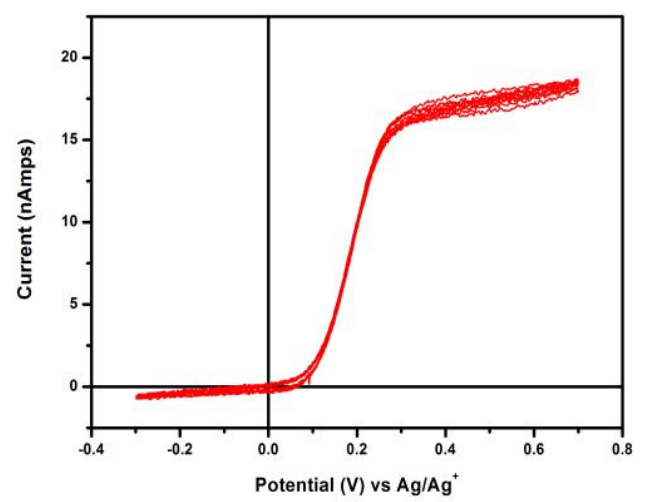

C

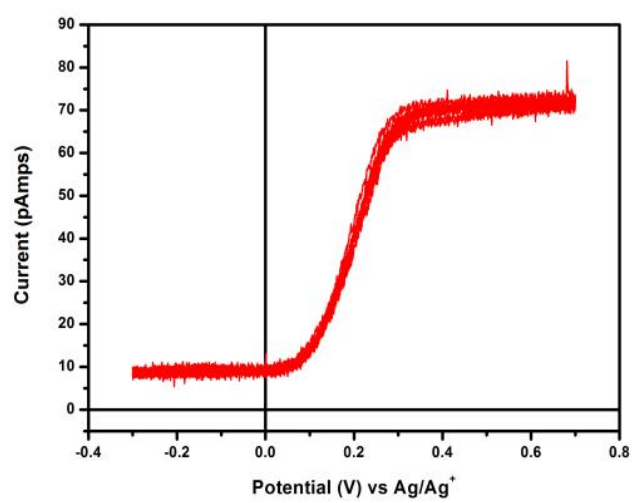

b

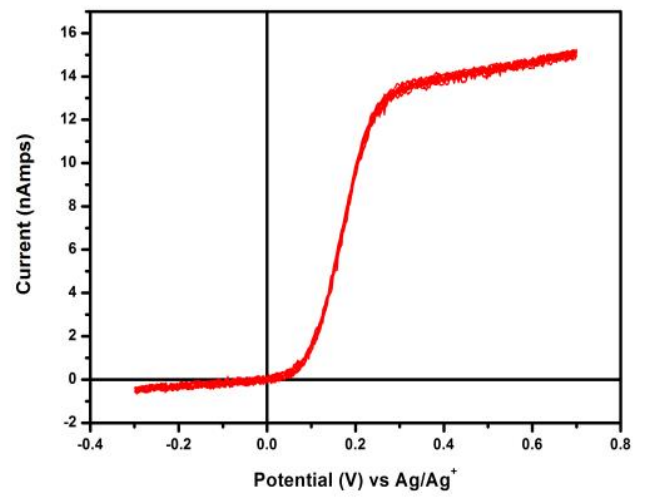

d

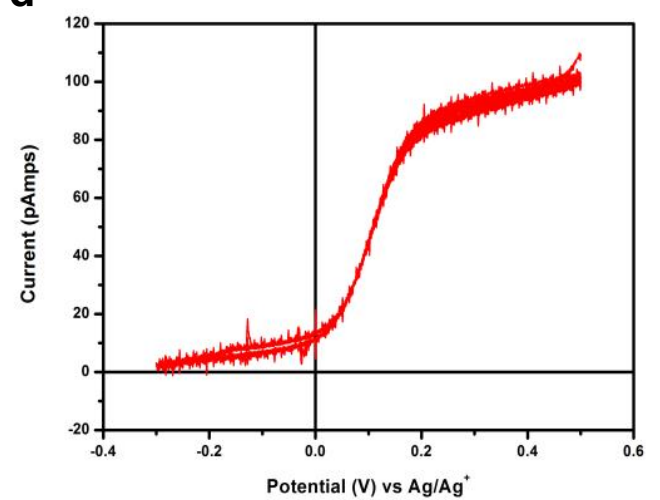

Figure 3: Cyclic voltammetry of $1 \mathrm{mM}$ ferrocene in acetonitrile without added supporting electrolyte at; a) gold microelectrode $(r \sim 20 \mu \mathrm{m}) ; b)$ platinum microelectrode $(r \sim 15 \mu \mathrm{m})$; $c)$ gold nanoelectrode (radius $73 \mathrm{~nm}$ ) and d) platinum nanoelectrode (radius $90 \mathrm{~nm}$ ). The unsmoothed CV's of gold and platinum microelectrodes were measured at $20 \mathrm{mV} / \mathrm{s}$ and nanoelectrodes at $10 \mathrm{mV} / \mathrm{s} \mathrm{scan}$ rates for 5 cycles.

The voltammetric profiles of micro and nanoelectrodes exhibits the ideal current profile sigmoidal shape, with no hysteresis on the reverse scan as shown in Figure 3. The negligible current variations in the plateau region of the profiles, shown in Figure $4 \boldsymbol{c}$ and $\boldsymbol{d}$, for the gold and platinum nanoelectrodes were of the orders of picoamperes at a scan rate of $50 \mathrm{mV} / \mathrm{s}$. These current spikes could be due to ohmic resistance or overlay capacitance, which is known to occur at electrodes characterised in the absence of supporting electrolyte. ${ }^{41,48}$ The radius of each electrode was calculated from the diffusion limited steady-state current response in ferrocene for the disk-shaped electrodes using the following equation: ${ }^{32}$

$$
i_{s s}=4 n F D C_{b} a
$$

where $n$ is the number of electrons transferred per molecule, $F$ is the Faraday constant $(96,485 \mathrm{C} / \mathrm{mol}), D$ is the diffusion coefficient of ferrocene in acetonitrile $\left(2.3 \times 10^{-5} \mathrm{~cm}^{2} / \mathrm{s}\right),{ }^{49} C_{b}$ is the bulk concentration of ferrocene $\left(\mathrm{mol} / \mathrm{cm}^{3}\right)$ and $a$ is the radius of the electrode. 
a

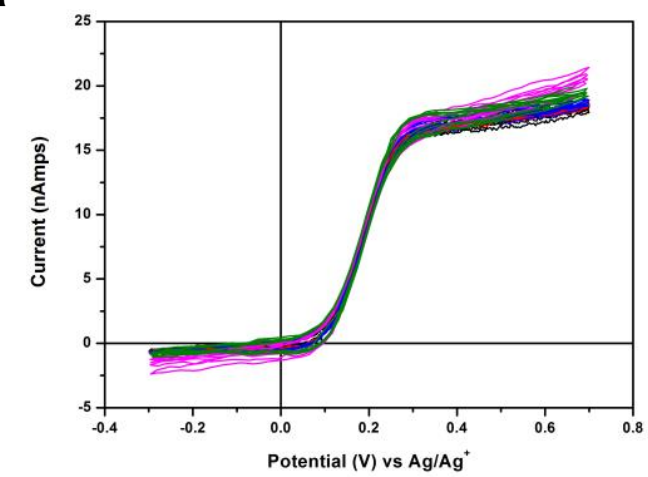

C

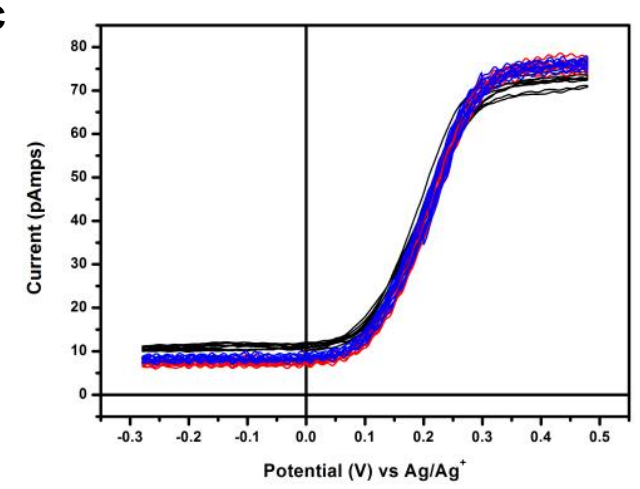

b

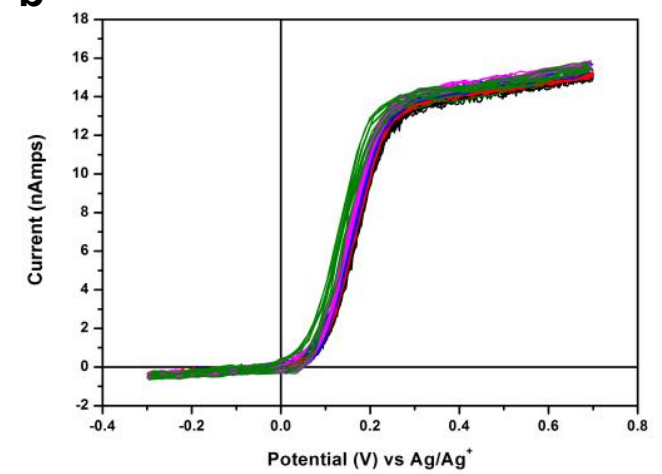

d

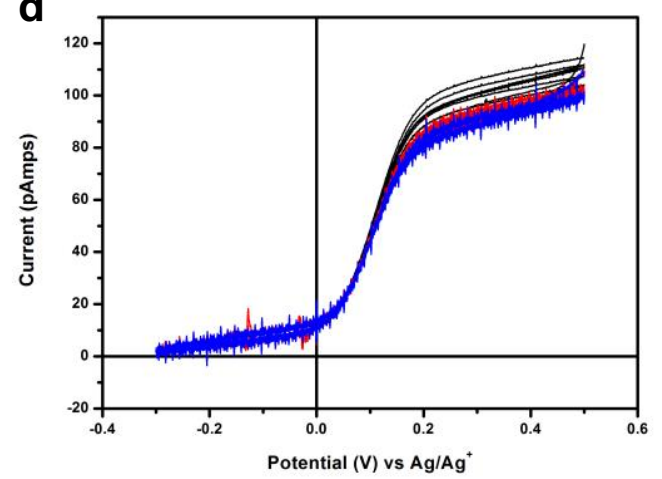

Figure 4: Cyclic voltammetric performance of fabricated electrodes in ferrocene, in the absence of supporting electrolyte, at different scan rates; $a)$ and b) gold $(r \sim 20 \mu m)$ and platinum microelectrodes $(r \sim 15 \mu \mathrm{m}$ ) at 20 (black), 50 (red), 100 (blue), 150 (green) and $200 \mathrm{mV} / \mathrm{s}$ (pink); c) gold $(r \sim 73 \mathrm{~nm})$ and d) platinum nanoelectrodes $(r \sim 90 \mathrm{~nm})$ at 10 (black), 20 (red) and $50 \mathrm{mV} / \mathrm{s}$ (blue).

The radii of the nano and microelectrodes were calculated to be in the ranges of $100-150 \mathrm{~nm}$ and $15-20 \mu \mathrm{m}$ (radii between of $1-10 \mathrm{~nm}$ for gold and platinum nanoelectrodes in S1 and S2), respectively, using the diffusion controlled steady-state currents. The cyclic voltammetry of the $\mathrm{Fc} / \mathrm{Fc}^{+}$redox couple confirmed the dimensions observed in the FE-SEM images. These data provide evidence that good quality; flat disk-shaped, leak-free, non-recessed electroactive micro and nanoelectrodes were obtained. The cyclic voltammetric behaviour of the micro and nanoelectrodes were recorded in acetonitrile without added supporting electrolyte. ${ }^{40,48}$ The sigmoidal shape voltammograms with steady-state limiting current profiles obtained from the micro and nanoelectrodes, proves that a good seal and quality polished electrodes were produced. ${ }^{34,50}$ Since the cyclic voltammetry current profiles are independent of applied scan rate (Figure 4), theory indicates that the electrodes are highly stable and are leak/crack free and, thus, exhibit excellent electrochemical performance. ${ }^{41}$

\section{Detection of Nanomolar Silver in Chloride-Free PB using Anodic Stripping Voltammetry}

Cyclic voltammetry was carried out at a platinum macroelectrode in a $1 \mu \mathrm{M}$ solution of silver nitrate in chloride-free PB ( $\mathrm{pH}$ - 7.4) to identify the optimal parameters for silver deposition and stripping analysis as illustrated in Figure 5. The cyclic voltammetry profile features a stripping peak oxidation potential at $0.32 \mathrm{~V}\left(\mathrm{Ag}^{\circ}\right.$ to $\left.\mathrm{Ag}+\right)$ and reduction peak at $-0.3 \mathrm{~V}\left(\mathrm{Ag}+\right.$ to $\left.\mathrm{Ag}^{\circ}\right)$. Silver concentrations ranging from $1-80 \mathrm{nM}$ in chloride-free $\mathrm{PB}$ were investigated using optimal conditions as follows; deposition potential $-0.3 \mathrm{~V}$ vs $\mathrm{Ag} / \mathrm{AgBr}$ was applied for 60 seconds and 30 seconds, and stripped at 
10 and $100 \mathrm{mV} / \mathrm{s}$ for the micro and nanoelectrodes, respectively. The cyclic voltammetry data for a $1 \mu \mathrm{M}$ silver nitrate solution were collected using both saturated calomel and an $\mathrm{Ag} / \mathrm{AgBr}$ quasireference electrode. Results indicated that the $\mathrm{Ag} / \mathrm{AgBr}$ quasi-reference electrode was a more suitable reference electrode for silver detection experiments.

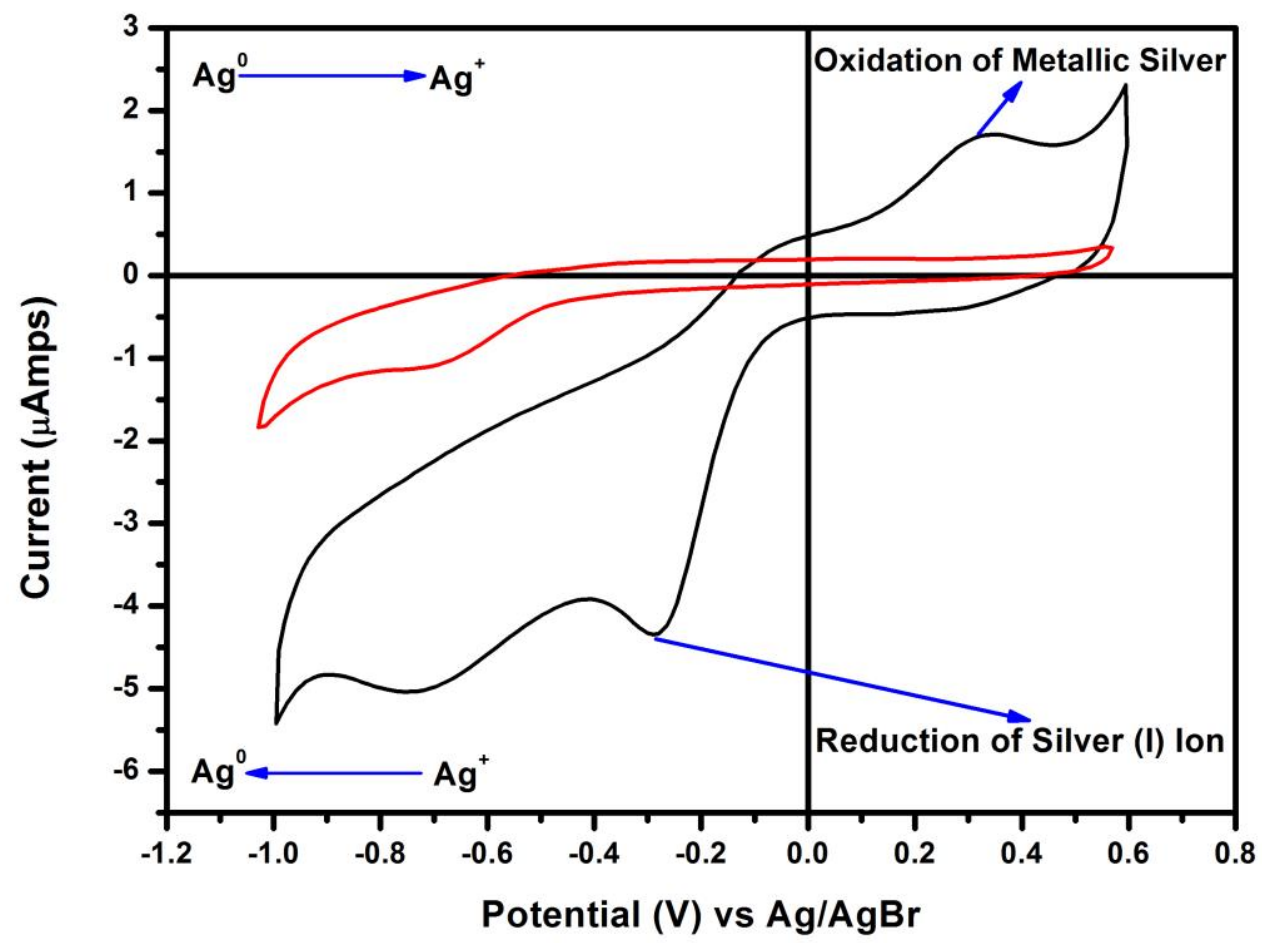

Figure 5: Cyclic voltammetry of $1 \mu \mathrm{M}$ concentration of $\mathrm{AgNO}_{3}$ in chloride-free $\mathrm{PB}$ at a gold macroelectrode against $\mathrm{Ag} / \mathrm{AgBr}$ (black) and blank chloride-free $\mathrm{PB}$ (red). The oxidation of silver was observed at a potential of $0.32 \mathrm{~V}$ and a reduction peak at $-0.3 \mathrm{~V}$ and reduction of dissolved $\mathrm{O}_{2}$ at $-0.75 \mathrm{~V}$. Scan rate was $100 \mathrm{mV} / \mathrm{s}$.

In this work, the electrodes were cleaned by cycling in $0.1 \mathrm{M}$ sulphuric acid until reproducible characteristic profiles were obtained ( $S 3$ and $S 4$ ). As reported in the literature, thorough electrode cleaning enhances the reproducibility of the stripping analysis. The higher the renewable surface available for deposition, the greater the reproducibility obtained. ${ }^{51,52}$ The background correction of stripping peaks (Figure 6 ) allows quantification of the total stripping charge during oxidation of silver even for short deposition duration times and at ultra-low concentrations (nanoelectrode - 30 seconds deposition) ${ }^{52}$ The percentage error in the background correction, decreased when the optimal deposition potential $\quad-0.3 \mathrm{~V}$ and deposition duration were used to deposit the silver. ${ }^{19}$ It has been reported that calibration curves generated using charge instead of peak current have higher correlation coefficients for silver detection. ${ }^{53}$ 


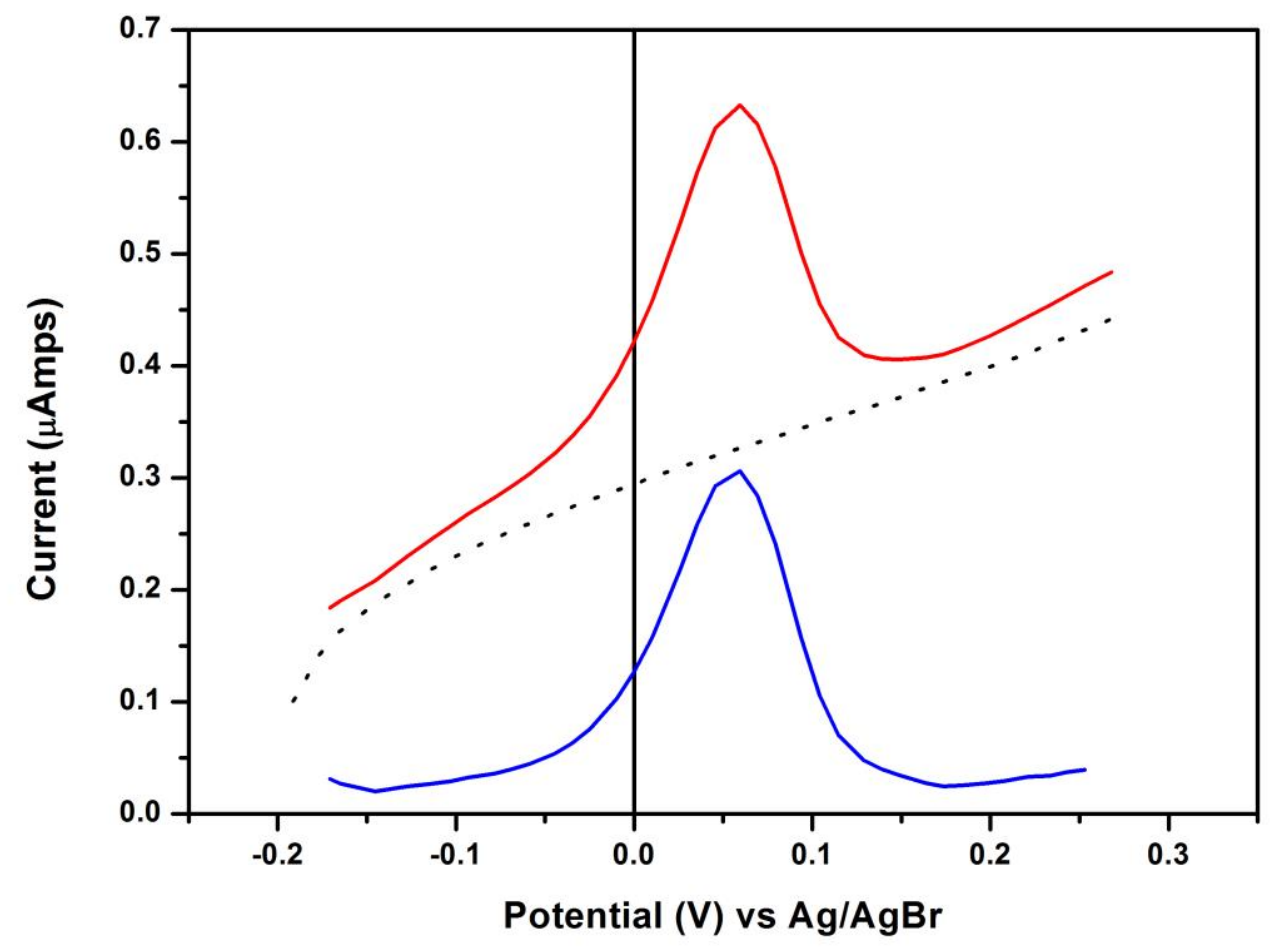

Figure 6: Typical experimental stripping peak subtraction (red) using the background profile (dotted), and the subtracted peak (blue), was used to calculate the peak charge. The stripping peak of silver $(1 \mu \mathrm{M})$ in chloride-free $P B$ in $10 \mathrm{mV} / \mathrm{s}$ scan rate at platinum microelectrode $(r \sim 10 \mu \mathrm{m})$.

\section{Effect of Chloride}

Chloride-free phosphate buffer solution was used in this work, in order to eliminate the formation of silver chloride precipitates $\left(\mathrm{Ag}^{+} \mathrm{Cl}^{-}\right.$complexations are in the order of $\left.10^{-9} \mathrm{M}\right)$ and to obtain reproducible stripping charge values for silver concentrations as low as $1 \mathrm{nM}$. Further contamination of chloride was eliminated by replacing the saturated calomel reference electrode with an $\mathrm{Ag} / \mathrm{AgBr}$ quasi-reference electrode. The effect of chloride ions on the stripping of silver was studied by analysing the anodic stripping peak in the presence and absence of chloride ions. It is found that in the presence of chloride, there is a shift in the anodic stripping peak to less positive potentials and an additional peak appears in comparison with the stripping peak in the absence of chloride ions as shown in Figure 7a and Figure $\mathbf{7 b} .^{54}$ From Figure $7 \mathbf{a}$, we observe a doublet of silver stripping peaks at $0.05 \mathrm{~V}$ and $-0.05 \mathrm{~V}$ vs SCE.

The presence of chloride ions in high concentrations results in poor reproducibility of silver stripping analysis. The narrowing of the silver stripping peak in the presence of chloride ions was also observed, and this reportedly is due to the formation of insoluble silver chloride nanoparticles. ${ }^{22,23,55}$ Epple et al., reported that silver in biological buffers tends to precipitate as silver chloride nanoparticles and $\mathrm{AgCl}$ colloids, which are toxic to cells. The authors also reported that, in PBS, silver chloride nanoparticles were formed $\left(500-1000 \mathrm{~nm}\right.$ in diameter), with a $\mathrm{Cl}^{-}$concentration of $0.14 \mathrm{M}$ and $0.25 \mu \mathrm{g} / \mathrm{L}(2.3 \mathrm{nM})$ of $\mathrm{Ag}^{+}$in the aqueous solution. ${ }^{56}$ The concentration gradient of silver and silver chloride nanoparticles at the electrode-electrolyte interface hugely impacts the 
reproducibility of silver anodic stripping profiles. The additional anodic stripping peak arises due to the formation of silver chloride, after metallic silver oxidation, in the presence of chloride.$^{54} \mathrm{~A}$ single stripping peak was observed in Figure $7 \boldsymbol{b}$, indicating that there is no formation of $\mathrm{AgCl}$ and that monolayer deposition of silver (no silver chloride) occurs at the micro and nano electroactive surface. ${ }^{57}$

a

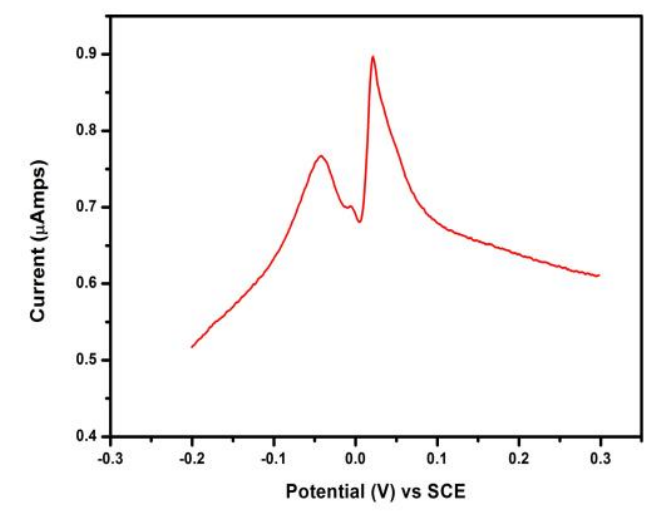

C

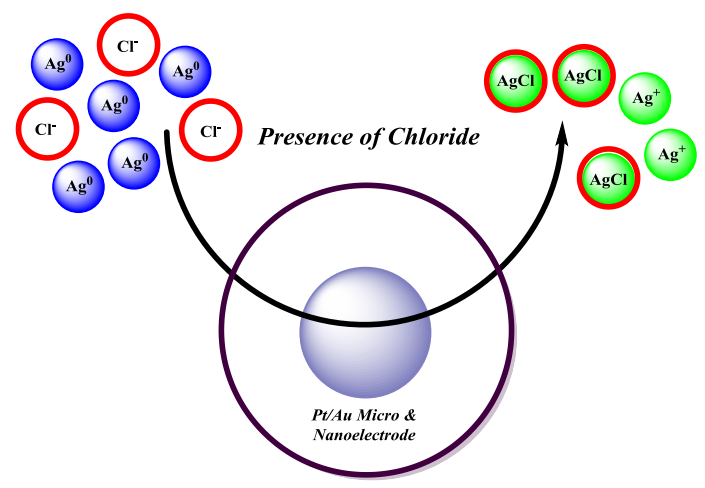

b

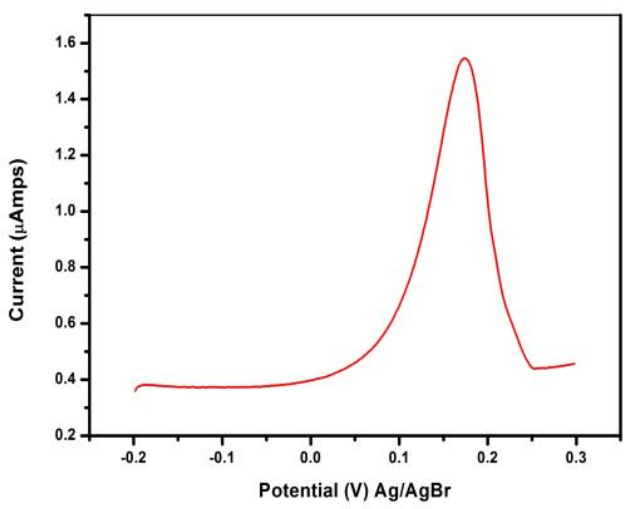

d

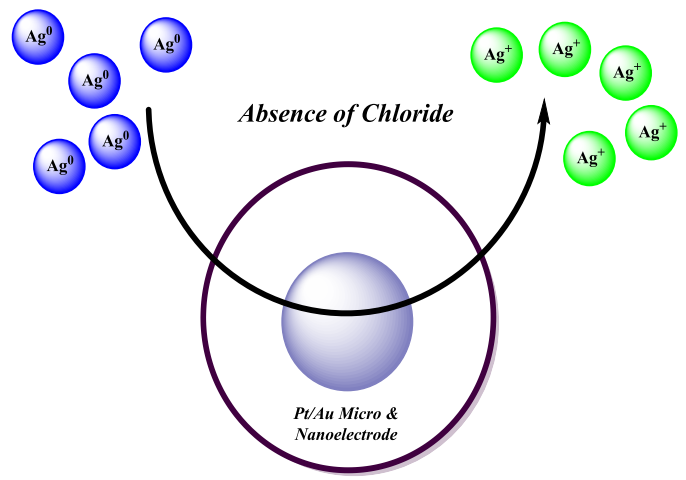

Figure 7: Stripping peak of $1 \mu M$ concentration of silver at deposition duration - $1 \mathrm{~min}$; deposition potential - $0.3 \mathrm{~V}$; scan rate $10 \mathrm{mV} / \mathrm{s}$. a) PB containing chloride vs SCE reference electrode (multiple peaks at $0.05 \mathrm{~V}$ for oxidation of $\mathrm{Ag}$ to $\mathrm{Ag}^{+}$and $-0.05 \mathrm{~V}$ for oxidation of $\mathrm{Ag}$ to $\mathrm{AgCl}$ ) b) Chloride-free $P B$ solution vs $\mathrm{Ag} / \mathrm{AgBr}$ reference electrode (single silver oxidation peak at $0.18 \mathrm{~V}$ ). Graphical representation of the influence of chloride c) presence and d) absence of chloride in silver detection.

\section{Effect of Buffer Molarity}

A comparison of stripping peaks at platinum nanoelectrodes in $0.1 \mathrm{M}$ and $0.01 \mathrm{M}$ at chloride-free $\mathrm{PB}$, $\mathrm{pH} 7.4$ was conducted (Figure 8). The stripping peaks obtained in $0.1 \mathrm{M}$ PB solution were much sharper than those obtained in $0.01 \mathrm{M} \mathrm{PB}$, and the total charge transferred during the oxidation of silver for $0.01 \mathrm{M} \mathrm{PB}$ was less than charges recorded in $0.1 \mathrm{M} \mathrm{PB}$. The difference in the charge is due to concentration of electrolyte of $0.01 \mathrm{M}$ having much less ions to carry current, which highly influence the shape of the stripping peak. The increase in the concentration of phosphate, in the case of $0.1 \mathrm{M} \mathrm{PB}$, also has a direct impact - it increases the electrochemical accessibility of oxidised silver (I) ions at the surface of the micro and nanoelectrodes. ${ }^{58}$ The phosphate ions present in PB solution, specifically the dibasic anion $\left(\mathrm{HPO}_{4}^{2-}\right)$, greatly influence the dynamics of silver oxidation by 
shifting the oxidation potential to less positive values (S5) and also affects the shape of the stripping peak. ${ }^{58}$ In both PB concentrations at $\mathrm{pH} 7.4$, there was no silver chloride formation, thus, there are no impurities which influence the diffusion coefficient of silver ions or the rate constant for silver oxidation. $^{54}$

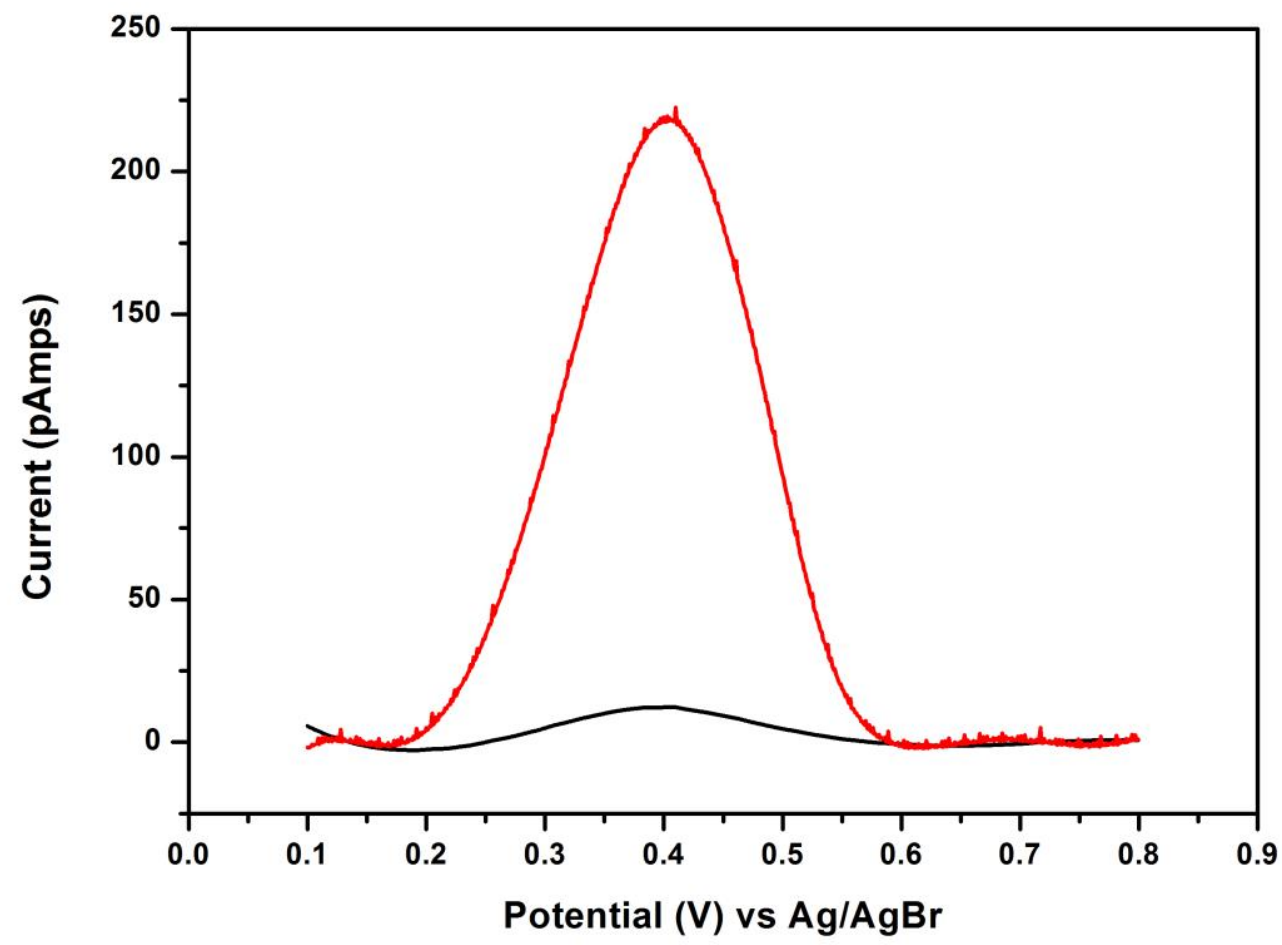

Figure 8: Comparison of the stripping peak for $80 \mathrm{nM}$ concentration of silver performed in $0.01 \mathrm{M}$ (black) and $0.1 \mathrm{M}$ (red) in chloride-free $P B$, at a scan rate of $10 \mathrm{mV} / \mathrm{s}$ obtained at platinum nanoelectrode $(90 \mathrm{~nm})$.

Detailed reviews of the literature for the determination of ultra-low concentrations of silver at carbon electrodes have been reported, and provide an insight into electrolytes used $\left(\mathrm{HNO}_{3}\right.$, acetate buffer, $\mathrm{KCl}$ and $\left.\mathrm{NH}_{4} \mathrm{NO}_{3}\right)$ and $\mathrm{pH}$ range $(1-5.5){ }^{11,15,59}$ These data indicate that silver oxidation is $\mathrm{pH}$ dependant ( $\mathrm{pH}$ range $1-5.5$ ). ${ }^{60}$ The linearity of each calibration plot increased as the size of the electrode decreased for lower concentrations of silver, and can be attributed to the enhanced electrochemical properties of nanoelectrodes compared to conventional electrodes. Mass transfer at micro and nanoelectrodes is governed by radial diffusion which promotes the deposition of silver on the surface, thus improving the sensitivity of the electrode. A nonzero intercept was observed in the regression plots for both micro and nanoelectrodes (Figure 9). The zero intercept effect is due to the influence of the stripping peak shape and height. From the stripping charge plotted against the concentration of silver, it is evidently clear that the plot is linear in the concentration range of 1-80 $\mathrm{nM}$. The peak shape is profoundly influenced by the presence of chloride (narrow and sharper peaks were observed in the presence of chloride Figure $7 \boldsymbol{a}$ ), and peak height is $\mathrm{pH}$ dependent. ${ }^{11,14,23,59}$ 
a

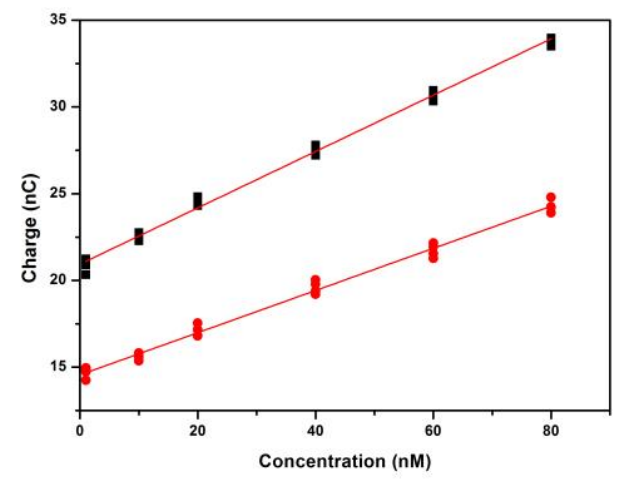

C

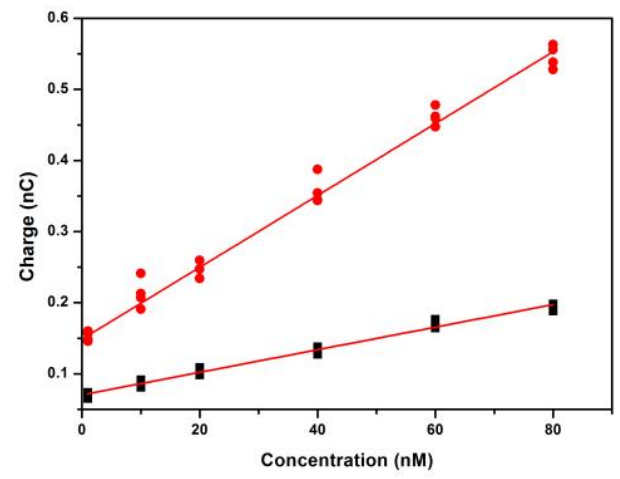

b

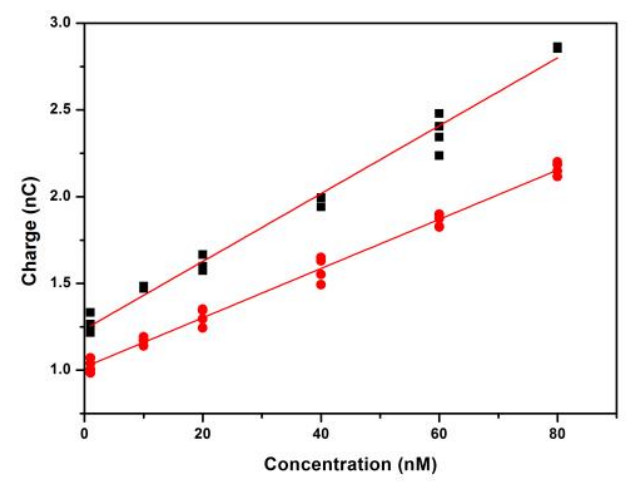

d

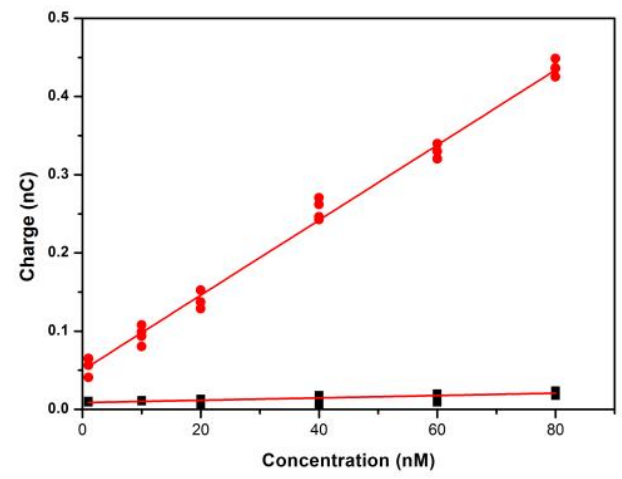

Figure 9: Linear regression plot for $0.01 \mathrm{M}$ (black squares) and $0.1 \mathrm{M}$ (red circles) $\mathrm{PB}(\mathrm{pH} 7.4)$ at a) gold $(r \sim 20 \mu \mathrm{m})$, b) platinum microelectrodes $(r \sim 15 \mu \mathrm{M})$, c) gold $(r \sim 73 \mathrm{~nm})$, and d) platinum nanoelectrode $(60 \mathrm{~nm})(d)$ with silver concentration ranging from $1 \mathrm{nM}$ to $80 \mathrm{nM}$. Each plot represents four independent sets of experimental data obtained at the same nanoelectrodes.

From the regression plots shown in Figure 10, platinum and gold nanoelectrodes with $\mathrm{R}^{2}$ values of 0.992 and 0.974 were suitable electrodes for detection and quantification of ultra-low concentrations of silver. Maria et al, studied the influence of acetate buffer $(\mathrm{pH}-5.2)$, citrate buffer $(\mathrm{pH}-3.0)$ and PBS ( $\mathrm{pH}-7.0)$ on the determination of silver by DPV. The authors concluded that acetate buffer $\mathrm{pH}$ 5.2, is a suitable medium for silver stripping analysis. ${ }^{14}$ Detection and determination of silver in biological buffers at neutral $\mathrm{pH}$ has been carried out with poor reproducibility. In this work chloridefree $\mathrm{PB}, \mathrm{pH} 7.4$, gave good reproducibility for the stripping analysis of silver. The experimental conditions facilitated deposition and stripping of silver at the electrode surface without impurities $\left(\mathrm{AgCl}\right.$ and $\left.\mathrm{Ag}_{3} \mathrm{PO}_{4}\right)$. Moreover, micro and nanoelectrodes provide a higher surface area for metal deposition yeilding high sensitivity even at ultra-low concentrations of silver $(1 \mathrm{nM})$. Thus, the detection and quantification of silver in biological buffer is possible at neutral $\mathrm{pH}$. The stripping charges were calculated and plotted against silver concentrations to construct calibration curves. Using the linear regression model,Figure 7 the data signify that the micro and nanoelectrodes exhibit excellent stability and reproducibility, exhibiting linear ranges for silver concentrations of $1-80 \mathrm{nM}$ in chloride-free PB at $\mathrm{pH}$ 7.4. 


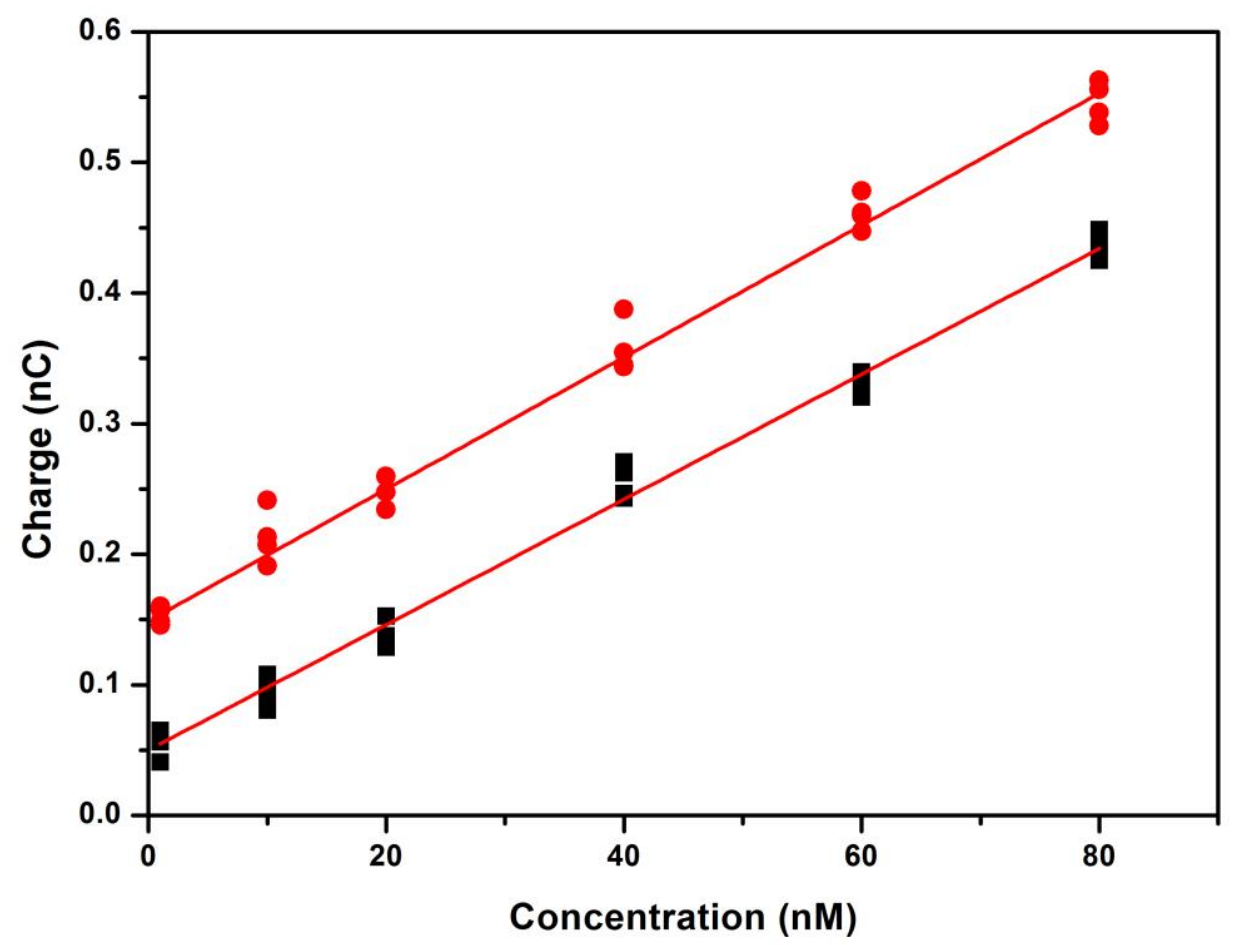

Figure 10: Comparison of the calibration curves of platinum (black squares) and gold nanoelectrodes (red circles) in $0.1 \mathrm{MPB}$ (deposition duration - 30 seconds and potential - $0.3 \mathrm{~V} v \mathrm{~s} \mathrm{Ag} / \mathrm{AgBr}$ ). For each concentration, at least four independent sets of experimental data at the same nanoelectrode were obtained. The R-square value from the calibration curves indicates that platinum nanoelectrodes $\left(R^{2}-0.992\right)$ and gold nanoelectrodes $\left(R^{2}-0.974\right)$ are suitable substrates for silver detection in $P B$, pH 7.4 . 


\section{Conclusion}

In this work, the electrochemical detection and determination of silver in chloride-free $\mathrm{PB}, \mathrm{pH} 7.4$, is presented. Micro and nanoelectrodes of gold and platinum were fabricated using the laser puller method, characterised by FE-SEM and the redox probe ferrocene, and exhibit good quality sealing and stability. We have demonstrated that by using the optimised laser pulling parameters for gold and platinum, micro and nanoelectrodes can be successfully fabricated. The fabricated micro and nanoelectrodes were successfully utilised in the determination of ultra-low concentration of silver in chloride-free $\mathrm{PB}, \mathrm{pH} 7.4$, yielding highly reproducible results. This study also explored the effects of chloride and phosphate ions in silver sensing. Eliminating chloride ions and using an $\mathrm{Ag} / \mathrm{AgBr}$ quasireference electrode, provides an excellent system for the detection of nano and sub-nanomolar concentrations of silver. This work will provide a platform for further detection and studies into the mechanism of action of silver-based drugs via electrochemistry, at single cell level for both in vitro and in vivo conditions.

\section{Acknowledgements}

The work performed in the Applied Electrochemistry Group (AEG) at FOCAS Institute, Dublin Institute of Technology was funded by Fiosraigh Dean of Graduate Research School Award. We would like to thank, Dr Brain Gorey, FOCAS, Dublin Institute of Technology (FE-SEM images). The FE-SEM imaging was carried out at the Nano Research Facility in Dublin City University, funded under the Programme for Research in Third Level Institutions (PRTLI) Cycle 5. We would also like to thank, ELIRI, Moldova for generously donating glass-sealed gold microwires for fabrication of the gold nanoelectrodes.

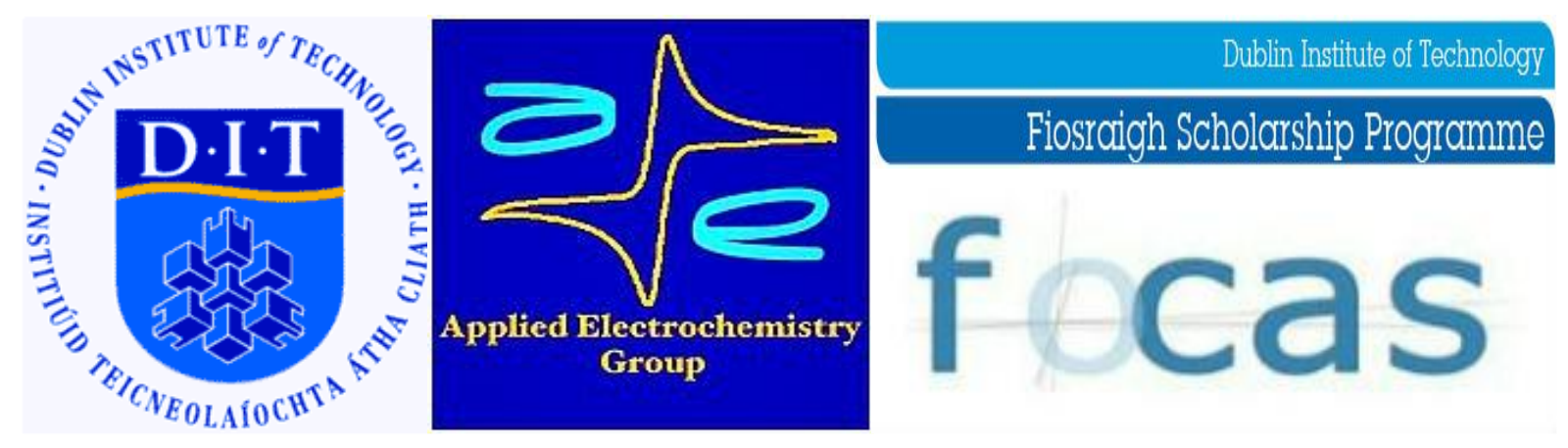




\section{References}

(1) Fricker, S. P. Dalt. Trans. 2007, No. 43, 4903-4917.

(2) Ndagi, U.; Mhlongo, N.; Soliman, M. E. Drug Des. Devel. Ther. 2017, 11, 599-616.

(3) Frezza, M.; Hindo, S.; Chen, D.; Davenport, A.; Schmitt, S.; Tomco, D.; Dou, Q. P. Curr. Pharm. Des. 2010, 16 (16), 1813-1825.

(4) Rijt, S. H. Van; Sadler, P. J. Drug Discov. Today 2010, 14, 1089-1097.

(5) Banti, C. N.; Hadjikakou, S. K. Metallomics 2013, 5 (6), 569.

(6) Thornton, L.; Dixit, V.; Assad, L. O. N.; Ribeiro, T. P.; Queiroz, D. D.; Kellett, A.; Casey, A.; Colleran, J.; Pereira, M. D.; Rochford, G.; McCann, M.; O’Shea, D.; Dempsey, R.; McClean, S.; Kia, A. F. A.; Walsh, M.; Creaven, B.; Howe, O.; Devereux, M. J. Inorg. Biochem. 2016, $159,120-132$.

(7) Biersack, B.; Ahmad, A.; Sarkar, F. H.; Schobert, R. Curr. Med. Chem. 2012, 19 (23), 39493956.

(8) Chernousova, S.; Epple, M. Angew. Chemie - Int. Ed. 2013, 52 (6), 1636-1653.

(9) Holt, K. B.; Bard, A. J. Biochemistry 2005, 44 (I), 13214-13223.

(10) Guggenbichler, J. P.; Böswald, M.; Lugauer, S.; Krall, T. Infection 1999, 27 (Supplement 1), S16-S23.

(11) Davies, T. J. Analyst 2016, 141 (15), 4742-4748.

(12) Zhiani, R.; Ghanei-Motlag, M.; Razavipanah, I. J. Mol. Liq. 2016, 219, 554-560.

(13) Liu, L.; Wang, C.; Wang, G. Anal. Methods 2013, 5 (20), 5812-5822.

(14) Radulescu, M. C.; Chira, A.; Radulescu, M.; Bucur, B.; Bucur, M. P.; Radu, G. L. Sensors 2010, 10 (12), 11340-11351.

(15) Mikelova, R.; Baloun, J.; Petrlova, J.; Adam, V.; Havel, L.; Petrek, J.; Horna, A.; Kizek, R. Bioelectrochemistry 2007, 70 (2), 508-518.

(16) Bard, A. J. J. Electroanal. Chem. 1963.

(17) Perone, S. P. Anal. Chem. 1963, 35 (13), 2091-2094.

(18) Bansod, B. K.; Kumar, T.; Thakur, R.; Rana, S.; Singh, I. Biosens. Bioelectron. 2017, 94 (March), 443-455.

(19) Wang, J.; Greene, B. Anal. Chim. Acta 1982, 144 (C), 137-145.

(20) Dospivova, D.; Hynek, D.; Trnkova, L.; Hubalek, J. In Setkání fyzikálních chemiki̊ a elektrochemiků, Květen; 2012; pp 3-8.

(21) Davies, T. J. Analyst 2016, 141 (15), 4742-4748.

(22) Dong, S. yudong wang. Anal. Chim. Acta 1988, 212, 341-347.

(23) Schildkraut, D. E.; Dao, P. T.; Twist, J. P.; Davis, A. T.; Robillard, K. a. Environ. Toxicol. Chem. 1998, 17 (4), 642-649.

(24) Li, M.; Gou, H.; Al-Ogaidi, I.; Wu, N. ACS Sustain. Chem. Eng. 2013, 1 (7), 713-723. 
(25) Wu, Y.; Hu, S. Indian J. Chem. - Sect. A Inorganic, Phys. Theor. Anal. Chem. 2005, 44 (5), 891-898.

(26) Wain, A. J. Wadhawan, J. D., Compton, R. G., Eds.; Electrochemistry; Royal Society of Chemistry: Cambridge, 2013; Vol. 12, pp 44-86.

(27) Wang, Y.; Noël, J.-M.; Velmurugan, J.; Nogala, W.; Mirkin, M. V; Lu, C.; Guille Collignon, M.; Lemaître, F.; Amatore, C. Proc. Natl. Acad. Sci. U. S. A. 2012, 109 (29), 11534-11539.

(28) Donald, I. W.; Metcalfe, B. L. J. Mater. Sci. 1996, 31 (5), 1139-1149.

(29) Arrigan, D. W. M. Analyst 2004, 129 (12), 1157.

(30) Clausmeyer, J.; Schuhmann, W. TrAC - Trends Anal. Chem. 2016, 79, 46-59.

(31) Actis, P.; Tokar, S.; Clausmeyer, J.; Babakinejad, B.; Mikhaleva, S.; Cornut, R.; Novak, P.; Shevchuck, A. I.; Dougan, J. A.; Schuhmann, W.; Klenerman, D.; Rusakov, O. D. A.; Sviderskaya, E. V; Korchev, Y. E. ACS Nano 2014, No. 1, 875-884.

(32) Jena, B. K.; Percival, S. J.; Zhang, B. Anal. Chem. 2010, 82 (15), 6737-6743.

(33) Li, Y.; Bergman, D.; Zhang, B. Anal. Chem. 2009, 81 (13), 5496-5502.

(34) Danis, L.; Polcari, D.; Kwan, A.; Gateman, S. M.; Mauzeroll, J. Anal. Chem. 2015, 87 (5), 2565-2569.

(35) Mezour, M. A.; Morin, M.; Mauzeroll, J. Anal. Chem. 2011, 83 (6), 2378-2382.

(36) Shao, Y.; Mirkin, M. V.; Fish, G.; Kokotov, S.; Palanker, D.; Lewis, A. Anal. Chem. 1997, 69 (8), 1627-1634.

(37) Liu, B.; Rotenberg, S.; Mirkin, M. Anal. Chem 2002, 74 (24), 6340-6348.

(38) Yang, C.; Sun, P. Anal. Chem. 2009, 81 (17), 7496-7500.

(39) Sun, P.; Kitt, J.; Tran, N.; Dang, J.; Saavedra, D. P.; Hong, J.; Wampler, R.; Anz, S. Electroanalysis 2016, 28 (8), 1880-1884.

(40) Katemann, B. B.; Schuhmann, W. Electroanalysis 2002, 14 (1), 22-28.

(41) Zhang, Y.; Xu, S.; Qian, Y.; Yang, X.; Li, Y. RSC Adv. 2015, 5 (94), 77248-77254.

(42) Zhang, Y.; Xu, S.; Xiao, X.; Liu, Y.; Qian, Y.; Li, Y. Chem. Commun. 2017, 53 (19), 28502853.

(43) Sanford, A. L.; Morton, S. W.; Whitehouse, K. L.; Oara, H. M.; Lugo-Morales, L. Z.; Roberts, J. G.; Sombers, L. A. Anal. Chem. 2010, 82 (12), 5205-5210.

(44) Nioradze, N.; Chen, R.; Kim, J.; Shen, M.; Santhosh, P.; Amemiya, S. Anal. Chem. 2013, 85 (13), 6198-6202.

(45) ELIRI Research Institute, Moldova.

(46) Taylor, J. K.; Smith, E. R. Natl. Bur. Stand. 1939, 22 (1938), 307-314.

(47) Donald, I. W.; Metcalfe, B. L. J. Mater. Sci. 1996, 31 (5), 1139-1149.

(48) Bond, A. M.; Lay, P. A. J. Electroanal. Chem. Interfacial Electrochem. 1986, 199 (2), 285295. 
(49) Bard, A. J.; Faulkner, L. R. Electrochemical Methods: Fundamentals and Applications, 2nd Edition; 2000.

(50) Li, Y.; Wu, Q.; Jiao, S.; Xu, C.; Wang, L. Anal. Chem. 2013, 85 (8), 4135-4140.

(51) Hunag, S.-S. Analyst 1994, 119 (August), 1859-1862.

(52) Wang, J.; Li, R.; Huiliang, H. Electroanalysis 1989, 1 (5), 417-421.

(53) Goł, J.; Osteryoung, J. Anal. Chim. Acta 1986, 181 (C), 211-218.

(54) Toh, H. S.; Batchelor-Mcauley, C.; Tschulik, K.; Compton, R. G. Analyst 2013, 138 (15), $4292-4297$.

(55) Dong, S. Anal. Chim. Acta 1987, 199, 167-171.

(56) Loza, K.; Sengstock, C.; Chernousova, S.; Köller, M.; Epple, M. RSC Adv. 2014, 4 (67), 35290.

(57) Eisner, U. R. I.; Mark, H. B. J. Electroanal. Chem. Interfacial Electrochem. 1970, 24 (2-3), $345-355$.

(58) Navolotskaya, D. V.; Toh, H. S.; Batchelor-McAuley, C.; Compton, R. G. ChemistryOpen 2015, 4 (5), 595-599.

(59) Zhiani, R.; Ghanei-Motlag, M.; Razavipanah, I. J. Mol. Liq. 2016, 219, 554-560.

(60) Liu, J. Environ. Sci. Technol. 2010, 44 (6). 